\title{
ISLAMISASI DI SUMATERA UTARA: Studi Tentang Batu Nisan di Kota Rantang dan Barus
}

\author{
Suprayitno \\ Departemen Ilmu Sejarah, Fakultas Ilmu Budaya USU \\ Jl. Universitas No. 19 Kampus USU, Medan 20155 \\ e-mail: praitno@yahoo.com
}

\begin{abstract}
Abstrak: Manakala membicarakan tentang proses islamisasi di Indonesia, para ahli akan fokus pada pembahasan tentang Aceh. Pada hal di Sumatera Utara, khususnya di sekitar kota Medan dan Barus banyak dijumpai situs makam kuno yang membuktikan agama Islam sudah lama bertapak di daerah ini. Dengan menganalisis tipologi dan kronologi nisan Aceh dan inskripsi yang terdapat pada batu nisan di Kota Rantang dan Barus, Sumatera Utara diketahui bahwa proses islamisasi di Sumatera Utara sudah terjadi sejak abad ke-13 M. Proses islamisasi itu akhirnya membentuk sebuah komunitas politik bercorak Islam pada abad ke-13 M yakni munculnya Kerajaan Haru di Kota Rantang, Hamparan Perak.
\end{abstract}

\begin{abstract}
Islamization in North Sumatra: A Study of Gravestone in Rantang and Barus Cities. When talking about the process of islamization in Indonesia, many an expert will focus on discussing Aceh. Where as in North Sumatra, especially around the city of Medan and Barus many ancient gravestones found that proves the Islamic religion has long foothold in this area. By analyzing the typology and chronology of Aceh tombstones and inscriptions found in gravestones in the cities of Rantang and Barus, North Sumatra Province is known that the process of islamization in North Sumatra have occurred since the $13^{\text {th }}$ century $\mathrm{AD}$. The process of islamization was eventually formed a political community of Islam in the design of the 13th century $\mathrm{AD}$ ie the emergence of the Kingdom of Haru in the Kota Rantang, Hamparan Perak.
\end{abstract}

Kata Kunci: Islamisasi, tipologi, batu nisan, Kota Rantang, Barus, Kerajaan Aru

\section{Pendahuluan}

Dalam tiga kali seminar tentang sejarah masuk dan berkembangnya Islam di Indonesia (Medan 1963, Banda Aceh 1978 dan Kuala Simpang 1980) ${ }^{1}$ disimpulkan, bahwa agama

${ }^{1}$ A. Hasymy. Sejarah Masuk dan Berkembangnya Islam Di Indonesia (Medan: PT Almaarif, 
Islam datang langsung dari negeri Arab pada abad I H/7M dan daerah pertama yang menerima kedatangan Islam adalah Aceh. Tetapi dalam seminar di Kuala Simpang, Aceh Timur Kerajaan Peureulak sebagai kerajaan Islam pertama di Indonesia/Asia Tenggara menjadi isu penting dalam seminar tersebut, sehingga dimasukkan dalam point ke-2 kesimpulan seminar untuk diteliti lebih dalam.

Ada dua aspek penting yang perlu ditegaskan di sini berkaitan dengan seminar di Medan dan Aceh Timur. Pertama, Kerajaan Samudera Pasai adalah kerajaan Islam pertama mulai digugat. Kedua, Aceh sebagai daerah yang mula-mula menerima agama Islam atau pusat dakwah Islam juga dipertanyakan. Dada Meuraxa adalah orang pertama yang menegaskan bahwa Barus (Sumatera Utara) adalah daerah pertama di Indonesia yang menerima agama Islam, lebih awal daripada Samudera Pasai (Aceh).

Berdasarkan kajian terbaru di Barus² dan Kota Rantang, Hamparan Perak, Deli Serdang rasanya pantas mendiskusikan kembali berbagai pendapat mengenai proses islamisasi di Sumatera, khususnya di Sumatera Utara. Tulisan ini mencoba untuk memberikan penjelasan mengenai kedatangan agama Islam di Sumatera Utara berdasarkan kajian terhadap batu nisan tipe Aceh di Barus dan Kota Rantang. Namun sebelum itu akan dijelaskan apa yang dimaksud dengan Batu Nisan Aceh.

\section{Batu Nisan Aceh: Tipologi dan Kronologi}

Batu nisan Aceh adalah sebuah terminologi unik kepada sebuah karya seni agama melibatkan seni desain, kaligrafi dan sastra pada sebuah batu. Terminologi itu pertama kali muncul pada dekade kedua abad ke- $20^{3}$ dan dipopulerkan oleh Othman Mohd. Yatim pada tahun 1988. Kajian awal mengenai batu nisan masih tertumpu kepada hubungan antara status si-mati (makam keramat) dan adat pemakaman orang-orang Melayu/Islam, sedikit menyentuh soal asal-usul batu, klasifikasi dan tipologi (jenis). Baru setelah era kemerdekaan, para ahli ${ }^{4}$ mulai menganalisis tentang batu Aceh meliputi bentuk dasar,

1981); M. Arifin, Perkembangan Islam di Peureulak Khususnya dan Aceh Timur Umumnya (Langsa: Majelis Ulama Daerah Tk. II Kab. Aceh Timur, 1980).

${ }^{2}$ Claude Guillot, et al., Barus Seribu Tahun Yang Lalu (Jakarta-Paris: Kepustakaan Populer Gramedia, 2008).

${ }^{3}$ Istilah batu Aceh pertama kali diperkenalkan oleh H.S. Sircom pada tahun 1920 dalam artikelnya yang diterbitkan dalam Journal of the Federated Malay States Museum berjudul "Keramat in Lower Pahang" (Sicrom, 1920:153).

${ }^{4}$ Othman Mohd. Yatim, Batu Aceh Early Islamic Gravestones in Peninsular Malaysia (Kuala Lumpur: Museum Association of Malaysia c/o Muzium Negara,1988); Daniel Perret dan Kamaruddin A B. Razak, Batu Aceh Warisan Sejarah Johor (Johor Bahru: Yayasan Warisan Johor, 1999); Elizabeth Lambourn, "The formation of the Batu Aceh Tradition in Fifteenth-Century Samudera-Pasai," dalam Indonesia and the Malay World, Vol. XXXII No. 93 (London: Routledge: 2004), h.211- 248 dan Herwandi, Bungong Kalimah: Kaligrafi Islam Dalam Balutan Tasawuf Aceh Abad ke-16-18 M. (Padang: Universitas Andalas, 2003). 
kaligrafi, klas, tipologi dan bahkan sudah menyelidiki jumlah spesies batu nisan terutama di Semenanjung Malaysia. Bahkan Othman Mohd. Yatim melangkah lebih jauh dengan membuat kronologi penggunaan batu nisan Aceh.

Sebenarnya, istilah batu Aceh/Nisan Aceh lebih dikenal di Malaysia, daripada di Aceh sendiri. Di Indonesia, nisan kubur ditampilkan dalam berbagai bentuk dan ragam hias yang berbeda-beda. Bentuk nisan tersebut biasanya merupakan lanjutan dari masa-masa sebelumnya seperti bentuk phallus, meru, lingga dengan pola hias beraneka ragam. Menurut Ambary, berdasarkan pusat persebarannya dapat dibagi dalam empat tipe yaitu Aceh, Demak-Troloyo, Bugis-Makasar, dan lokal. Nisan tipe Aceh didasarkan pada nisan makam Malik al-Saleh yang merupakan makam paling tua di daerah tersebut. Nisan tipe ini tidak hanya terdapat di Aceh tetapi tersebar hingga di Sumatra Utara, Sumatra Barat, Semenanjung Malaya, Lampung, Banten dan Jakarta. Nisan tipe Demak-Troloyo didasarkan pada bentuk nisan Raden Patah di Demak dan beberapa makam kuna di Troloyo. Bentuk nisan tipe Demak-Troloyo tersebar di Pantai Utara Jawa dan daerah pedalaman, Palembang, Aceh, Riau, Banjarmasin dan Lombok. Nisan tipe Bugis-Makasar didasarkan pada makam raja-raja Goa dan Bone di Tamalate, Soppeng, dan Watang Lamuru. Nisan tipe demikian di luar Sulawesi Selatan dapat dijumpai di Sulawesi Tengah, Kalimantan Timur, dan Bima. Tipe nisan lokal merupakan bentuk nisan yang hanya terdapat di daerah tertentu. Sebagai contoh misalnya nisan yang terdapat di Ternate-Tidore, Jeneponto, dan Barus.

Nisan tipe Aceh didasarkan pada nisan makam Malik al-Saleh yang merupakan makam paling tua di daerah tersebut. Nisan tipe ini tidak hanya terdapat di Aceh tetapi tersebar hingga di Sumatra Utara, Sumatra Barat, Semenanjung Malaya, Lampung, Banten dan Jakarta.

Mengingat pentingnya informasi yang terkandung dalam batu nisan Aceh khususnya memuat nama tokoh dan tahun kematiannya, maka ia tidak boleh diabaikan ketika mendiskusikan tentang proses awal Islam di Sumatera/Indonesia. Berikut ini akan dijelaskan tipologi dan kronologi penggunaan batu nisan Aceh di Asia Tenggara, sebagai cara untuk mengetahui awal Islam di Sumatera Utara

Tipologi nisan dibuat berdasarkan bentuk formal nisan dengan membandingkan tipologi yang dibuat oleh Othman, Ambary, dan Herwandi. Ambary ${ }^{5}$ mengelompokkan nisan gaya Aceh dalam tiga kelas utama yaitu bentuk gabungan sayap-bucrane, bentuk persegi panjang, dan bentuk silindrik. Bentuk sayap-bucrane adalah nisan menyerupai tanduk kerbau, baik dalam wujud nyata maupun yang sudah digayakan. Bentuk persegi panjang adalah nisan-nisan berbentuk rectangular (segi empat tepat) yang pada bahagian puncaknya terdapat hiasan menjadi mahkota dari nisan tersebut. Nisan silindrik adalah nisan-nisan

${ }^{5}$ Hasan Muarif Ambary, "Kota Banda Aceh Sebagai Pusat Kebudayaan dan Tamaddun," dalam Kota Banda Aceh Hampir 1000 Tahun (Banda Aceh: Pemerintah Daerah Tk. II Banda Aceh, 1988), h. 12-14. 
yang berbentuk bulat seperti gada. Sedangkan Othman ${ }^{6}$ membaginya dalam dua kelas utama yaitu slab dan pillar. Nisan slab berbentuk dasar pipih, baik yang polos maupun yang telah dihiasai dan digayakan. Nisan pillar berbentuk dasar tonggak baik empat persegi maupun bulat.

Dengan mengambil perbandingan dari Othman dan Ambary, Herwandi ${ }^{7}$ mengelompokkan nisan berhias kaligrafi kepada tiga kelas utama yaitu pipih diberi kode A, blok diberi kode B, dan bulat diberi kode C. Berdasarkan klasifikasi utama itu beliau menyusun tipologi nisan dengan menyertakan ciri-ciri tambahan. Nisan pipih dibagi kepada empat jenis, yaitu A1, A2, A3, dan A4; nisan blok dibagi ke dalam dua jenis yaitu B1 dan B2; dan nisan berbentuk bulat dibagi ke dalam dua jenis yaitu C1 dan C2. Tiga kelas utama nisan di Aceh Besar dan Banda Aceh disusun dalam 8 jenis lengkap dengan atribut-atributnya. Sebenarnya terdapat lagi penggolongan tipologi batu nisan Aceh yaitu sebagaimana yang dibuat oleh Daniel Perret. Namun, Perret meneruskan metode yang dilakukan oleh Othman. Beliau menambahkan tiga tipologi lagi untuk batu nisan Aceh yang terdapat di Johor yaitu O, P, dan Q. Dari bentuk umum batu nisan yang terdapat di Johor, dapat dibedakan kepada 16 jenis; 9 berbentuk papan/pipih (A, B, C, D, F, N, O, Q) dan 7 berbentuk tiang (G, H, J, K, L, M, P).

Berdasarkan kajian lapangan terdapat temuan baru yang belum dimasukkan dalam tipologi-tipologi terdahulu dan tambahan lagi tipologi Herwandi terbatas kepada batu nisan berhias kaligrafi, maka dapat dibuat tipologi baru. Metode yang dilakukan untuk menentukan kelas nisan berdasarkan kepada metode Othman yang membagi morfologi nisan menjadi 6 bahagian yaitu; dasar (kaki), badan bahagian bawah, badan bahagian atas, bahu, kepala dan puncak. Metode ini merupakan yang terperinci sehingga ke hari ini. Sedangkan tipologi dibina berdasarkan ciri-ciri tambahan seperti sayap dan lengkungan pada bahu, puncak dan kepala.

Berdasarkan itu batu nisan seperti ini dikenali sebagai batu nisan Aceh. Dapat ditawarkan kode A (Aceh) diperkenalkan sebagai kode pertama klasifikasi nisan Aceh. Kode berikutnya berdasarkan kepada morfologi atau bentuk umum kesemua batu nisan Aceh, yaitu bentuk Silinder (S), bentuk segi empat - pipih yang tipis (P) dan bentuk segi empat - blok yang tebal (B). Maka, kode klasifikasi umum yang ditawarkan ialah AP, AB dan AS. Klasifikasi berikutnya berdasarkan kepada atribut tambahan seperti kehadiran sayap, bonggolan dan lengkungan pada bahu, puncak dan kepala. Berdasarkan itu maka ada 24 tipologi batu nisan Aceh yang tersebar di Sumatera khususnya dan Asia Tenggara pada umumnya.

Penyusunan kronologi terhadap berbagai jenis batu nisan yang terdapat di Asia Tenggara agak sukar karena dalam penyelidikan sebahagian besar batu nisan tidak memuat informasi tentang tokoh, tarikh dan lainnya. Sukar untuk memberikan sebuah pernyataan yang pasti kepada sebuah batu nisan digunakan pada suatu masa, karena ada sebuah jenis batu nisan digunakan dalam masa yang lama. Kronologi dalam tulisan ini hanya disusun berdasarkan

${ }^{6}$ Othman Mohd. Yatim, Batu Aceh Early Islamic Gravestones in Peninsular Malaysia (Kuala Lumpur: Museum Association of Malaysia c/o Muzium Negara, 1988), h. 26-31, 52-58.

${ }^{7}$ Herwandi, Bungong Kalimah: Kaligrafi Islam Dalam Balutan Tasawuf Aceh Abad ke-1618 M. (Padang: Universitas Andalas Padang, 2003), h. 98-100. 
pada tarikh yang pasti terdapat pada sebuah batu nisan, baik dari hasil survei selama ini maupun dari kajian terdahulu pada tempat yang berbeda.

Berdasarkan kronologi penggunaan batu Aceh, dapat ditegaskan bahwa batu nisan bentuk dasar pipih digunakan lebih awal daripada nisan jenis blok dan silindrik yaitu sejak awal abad ke-11 M. Nisan blok digunakan sejak awal abad ke-13 M, sedangkan nisan silindrik digunakan mulai abad ke-16 M. Kesimpulan ini berdasarkan tarikh pada nisan, bukan berdasarkan kepada naik turunnya sebuah kekuasaan politik seperti Kerajaan Aceh dan Samudera Pasai yang diperkirakan sebagai agen penyebar kesenian batu nisan Aceh. Memang tidak boleh dinafikan ada hubungan antara penyebaran budaya dengan kekuasaan politik. Namun dalam kasus batu nisan hanya Bustanus Salatin ${ }^{8}$ yang mencatat adanya perintah seorang penguasa untuk mengirimkan batu nisan dari Aceh ke Pahang. Perintah itu tidak boleh ditafsirkan sebagai terdapatnya campur tangan kekuasaan politik dalam urusan penyebaran batu nisan, sebab perkara itu bersifat kekeluargaan (non-politik dan ekonomi).

\section{Kronologi Batu Aceh di Asia Tenggara}

\begin{tabular}{|c|c|c|c|c|c|c|c|c|}
\hline \multirow{2}{*}{ Jenis } & \multicolumn{8}{|c|}{ Tarikh } \\
\hline & $11 \mathrm{M}$ & $12 \mathrm{M}$ & $13 \mathrm{M}$ & $14 \mathrm{M}$ & $15 \mathrm{M}$ & $16 \mathrm{M}$ & $17 \mathrm{M}$ & $18 \mathrm{M}$ \\
\hline AP1 & - & - & - & - & 4 & - & - & - \\
\hline AP2 & 1 & - & - & - & - & - & - & - \\
\hline AP3 & - & - & - & - & - & - & - & - \\
\hline AP4 & - & - & - & - & - & - & - & - \\
\hline AP5 & - & - & - & - & - & 2 & 1 & - \\
\hline AP6 & 1 & - & - & 1 & 1 & 3 & 1 & - \\
\hline AP7 & - & - & - & - & - & - & - & - \\
\hline AP8 & - & - & 1 & 1 & 8 & 3 & 1 & - \\
\hline AP9 & - & - & - & - & - & 1 & 3 & 1 \\
\hline AP10 & - & - & - & - & 1 & 12 & 7 & 3 \\
\hline AP11 & - & - & - & - & - & 4 & 1 & 1 \\
\hline AS1 & - & - & - & - & - & - & - & - \\
\hline AS2 & - & - & - & - & - & - & - & - \\
\hline AS3 & - & - & - & - & - & 1 & 1 & - \\
\hline AS4 & - & - & - & - & - & 1 & 2 & 1 \\
\hline AS5 & - & - & - & - & - & 1 & 4 & 3 \\
\hline AS6 & - & - & - & - & - & - & - & 1 \\
\hline AS7 & - & - & - & - & - & - & - & - \\
\hline AS8 & - & - & - & - & - & - & - & - \\
\hline AS9 & - & - & - & - & - & - & - & - \\
\hline AB1 & - & - & 1 & 1 & 1 & 8 & 4 & 2 \\
\hline $\mathrm{AB} 2$ & - & - & - & - & 1 & 5 & - & 1 \\
\hline AB3 & - & - & - & - & 1 & - & - & - \\
\hline $\mathrm{AB} 4$ & - & - & 1 & - & - & - & - & - \\
\hline
\end{tabular}

${ }^{8}$ Teuku Iskandar (ed.), Bustanu's Salatin oleh Nuruddin ar-Raniri (Kuala Lumpur: Dewan Bahasa dan Pustaka, 1966), h. 57. 
Nisan tertua sebagaimana disebutkan dalam tabel diatas adalah dari jenis AP2 dan AP6. Pada kedua jenis batu nisan itu tidak terdapat nama tokoh yang dimakamkan. Nisan AP6 ditemukan di Kampung Pematang Pasir, Pekan Pahang dengan tarikh 419H/1028M. Othman meragukan tarikh pada batu nisan itu, karena jenis tulisan yang digunakan lebih modern, tidak semasa dengan jenis batu tersebut dana dibuat tidak dengan tahun Hijrah ${ }^{9}$. Sementara nisan jenis AP2 ditemukan dalam sebuah survey bulan Juli 2010 di Kuta Lubhok, Lamreh, Aceh Besar. Kondisi nisan sudah tidak utuh, hanya satu panel yang dapat dibaca. Epigrafi ditulis dalam bahasa Arab yang menyebutkan bahwa orang yang dimakamkan di sini wafat pada hari Jum'at tanggal 22 bulan shafar 398 hijriah (5 Nopember 1007 M).

Nisan Kuta Lubhok ini apabila dihubungkaitkan dengan tokoh Sulaiman bin Sultan al Baasyir yang makamnya juga terdapat di Kuta Lubhok sangat relevan. Maksudnya adalah jika diteliti tahun wafat Sultan Sulaiman yaitu pada tahun Tsamaniata wa sitta mi'ah, $680 \mathrm{H}$ $(1211 \mathrm{M})$, maka diperkirakan dua abad (dua generasi) sebelum beliau atau kakek Sultan Sulaiman sudah beragama Islam, karena sudah menggunakan nama Baasyir (nama Muslim). Namun disayangkan bahwa nisan Kuta Lubhok tidak in situ dan tidak dikenali siapa nama tokoh atau orang yang mati. Walau bagaimanapun hal ini tidak mengurangi pentingnya pendapat bahwa pada abad ke-11 M sudah wujud pemukiman Muslim di kawasan Kuta Lubhok, Aceh Besar.

Sebenarnya nisan dengan tarikh abad ke-11 M ada tiga lagi, namun ketiganya tidak dapat dikenali tipologinya sebagai nisan Aceh. Dua di antaranya adalah prasasti Islam yang dijumpai di Vietnam dan Leran, Gersik (Jawa Timur). Keduanya bahkan sukar diidentifikasi sebagai sebuah batu nisan, karena tidak dalam keadaan utuh. Temuan di Leran Gersik, yang selama ini dikenali sebagai makam Fatimah binti Maimun yang meninggal 419 H/ 1028 M oleh Kallus ${ }^{10}$ dipahami sebagai barang impor dari Timur Tengah yang telah diubah fungsi sebagai sauh kapal atau jimat. Beliau menegaskan bahwa tokoh perempuan yang disebut dalam prasasti berasal dari golongan orang kebanyakan dan sukar diperkirakan bahwa pada masa itu telah ada komunitas Muslim di Jawa Timur. Sama seperti makam di Brunai. Makam di Brunai tidak dapat dipastikan sebagai batu Aceh atau bukan, karena jenis batunya dan dekorasinya lebih mirip dengan tipologi nisan yang banyak ditemukan di Barus dan Patani (Thailand).

Sepanjang abad ke-12 M, tidak atau tepatnya belum diketemukan nisan dari jenis manapun. Kekosongan data prasasti Islam ini mempersulit gambaran atau deskprispsi mengenai proses Islamisasi di Asia Tenggara umumnya dan Sumatera Utara khususnya. Nisan dengan tarikh abad ke-14 M kemudian ditemukan sebanyak 4 buah masing-masing di Barus, Lamreh, Kampung Meunasah Beringin, Pasai Aceh Utara, dan Kampung Pande, Banda Aceh. Keempat nisan itu hanya tiga yang dikenali jenis atau tipologinya yakni, AB4 pada Makam Sultan Sulaiman bin Abdullah bin al-Baasyir, 680H/1211M di Lamreh, AB1

${ }^{9}$ Othman Mohd. Yatim dan Halim Nasir, Epigrafi Islam Terawal di Nusantara. Kuala Lumpur: Dewan Bahasa dan Pustaka Kementerian Pendidikan Malaysia, 1990), h. 52-59.

${ }^{10}$ Claude Guillot dan Ludvik Kallus, Inskripsi Islam Tertua Di Indonesia (Jakarta: Gramedia, 2008), h. 11-31. 
pada Makam Sultan Ali Riayat Shah Ibn Munawar Syah ibn Almarhum Muhammad Alaiddin Shah, 670 H/1271 M di Kampung Pande, dan AP8 pada Makam Sultan Malik as-Saleh, 690H/ 1297M di Meunasah Beringin. Sementara nisan di Makam Tuanku Batu Badan yang menyebutkan nama Siti Tuhar Amisuri, 620H/1206 M tidak dapat dikenali tipologinya.

Jadi berdasarkan tabel di atas ditemukan bahwa sejak abad ke-15 sampai abad ke$18 \mathrm{M}$, data temuan batu nisan Aceh yang bertarikh sudah menunjukkan peningkatan terutama pada abad ke-16 dan $17 \mathrm{M}$. Peningkatan jumlah ini dapat dipahami mengingat pada periode ini Agama Islam telah berkembang dengan pesat di Asia Tenggara. Pusat-pusat peradaban Islam muncul di seantero Nusantara seperti di Kuta Raja (Banda Aceh), Banten, Demak, Johor bersamaan dengan hadirnya kerajaan Islam yang mendominasi perdagangan di kawasan itu. Istana-istana kerajaan tidak hanya berfungsi sebagai pusat pemerintahan, tetapi juga bandar perdangangan yang menjadi tempat pertemuan antara berbagai barang dan manusia dari berbagai pelosok dunia. Kota-kota/istana atau bandar perdagangan yang makmur akhirnya menjadi pusat peradaban Islam sebagai tempat lahirnya berbagai bentuk kesenian Islam termasuk seni Batu Nisan Aceh yang tersebar hampir ke seluruh pelosok Nusantara dan dapat dipakai sebagai alat bukti tentang proses penyebaran Islam di wilayah ini.

\section{Batu Nisan Kota Rantang dan Barus}

Pada sekitar abad ke 13-15 M, daerah Sumatera Utara terutama kawasan sepanjang Pantai Timur dari batas kerajaan Samudera Pasai (Pulau Kampai) sehingga ke muara Sungai Barumun (Rokan) merupakan daerah kekuasaan Kerajaan Aru/Haru. ${ }^{11}$ Memasuki abad ke-16 sehingga abad ke-17 M, daerah ini dikuasai oleh Kerajaan Aceh Darussalam. Berdasarkan itu seharusnya banyak batu nisan kuno di jumpai di kawasan ini, seperti halnya di Malaysia yang hampir satu abad menjadi daerah taklukkan Kerajaan Aceh.

Di Sumatera Utara, khususnya di sekitar kota Medan tidak banyak dijumpai situs makam kuno. Sejauh ini hanya enam makam saja yang pernah dijumpai di kawasan ini. Makam itu adalah di Klumpang, Kota Rantang, Hamparan Perak, Kabupaten Deli Serdang serta Mabar, Sukamulia di Kotamadya Medan, Pulau Kampai, Kabupaten Langkat dan Kompleks Makam di Barus. Makam di Klumpang, Mabar, dan Sukamulia tidak dapat diketahui lagi keberadaannya. Makam di Sukamulia adalah makam Raja Alamsyah, ayahanda Sultan Iskandar Muda yang gugur dalam serangan pasukan Aceh ke Aru abad ke-16 M. Di sini sekarang terdapat sebuah makam yang dikeramatkan dengan nama Datuk Merah. Apakah ini makam Raja Alamsyah, belum dapat dipastikan.

Di antara pertemuan Sungai Babura dan Sungai Deli, Cremer pada tahun 1889 pernah menjumpai bekas-bekas benteng dan makam-makam kuno yang ditumbuhi pohon-pohon

${ }^{11}$ Suprayitno, "Kota Rantang dan Hubungannya dengan Kerajaan Aru," dalam Harian Waspada (18 Mei 2008); A.C. Millner, et al.," A Note On Aru and Kota Cina," dalam Melayu Online.Com (13-15 Maret 2008). 
rindang dan dikeramatkan. ${ }^{12}$ Namun makam-makam inipun tidak diketemukan lagi. Makam Imam Sadiq ibn Abdullah di Klumpang, Hamparan Perak yang mangkat pada 998 H/1590 M juga tidak dijumpai lagi, tetapi dari gambar yang terdapat dalam laporan JP Moquette sebagaimana dikutip oleh Luckman Sinar ${ }^{13}$ diketahui jenis AP10.

Kota Rantang adalah sebuah desa di Kecamatan Hamparan Perak, Kabupaten Deli Serdang Sumatera Utara. Kota Rantang merupakan kawasan pesisir Pulau Sumatera. Kirakira 2 kilometer dari pemukiman penduduk, air sudah terasa asin. Lokasi situs berkedudukan $15 \mathrm{~km}$ arah barat laut dari kota Medan. Di desa itu bertemu Sungai Diski dan Sungai Semayang. Untuk sampai ke kawasan ini harus melalui perkebunan tebu PT. Nusantara II di Klambir Lima.

Situs Kota Rantang ditemukan oleh Tim Peneliti Arkeologi dari Pusat Penelitian dan Pengembangan Arkeologi Nasional Jakarta pada bulan April 2008. Mereka melakukan penelitian selama 12 hari di di desa "Mojopahit". Menurut Nani H. Wibisono, koordinator eskavasi, ditemukan pecahan batu nisan dan beberapa pecahan keramik dari Dinasti Yuan abad ke-13 sampai abad ke-14; Dinasti Ming abad ke-15, keramik Vietnam abad ke-14 sampai abad ke-16, keramik Thailand abad ke-14 sampai abad ke-16, keramik Burma abad ke14 sampai abad ke-16, dan keramik Khmer abad ke-12 sampai abad ke-14. Adapun batu nisan yang ada di lokasi bertuliskan syahadat tanpa tarikh. ${ }^{14}$ Walau demikian, makam-makam kuno yang diteliti bukan di desa Mojopahit, tetapi di beberapa lokasi yaitu di Dusun I dan II Kota Rantang Luar.

Situs Makam di Kota Rantang, dapat dibagi dalam empat lokasi. Pertama, di tebing sungai Sei Semayang, di bawah pohon pisang, pada kordinat 03 44' 09,4" LU (N), 98 35' 03,8" BT (E), dan ketinggian $19 \mathrm{~m}$ di atas permukaan laut. Kedua, berada di tebing Sungai Diski, di kebun penduduk orang Mandailing, pada kordinat 03 $44^{\prime} 14,7^{\prime \prime} \mathrm{LU}(\mathrm{N}), 98^{\circ} 34^{\prime} 43,6$ BT (E), dan ketinggian $18 \mathrm{~m}$ di atas permukaan laut. Kedudukan nisan sudah berserak dalam semak-semak, hanya tiga makam saja yang batu nisannya berdiri tegak. Ketiga, berada di sawah penduduk arah ke utara dari situs makam pertama dan kedua, sekitar 500 meter dari tebing gabungan Sungai Diski, pada kordinat 03 44' 33,1" LU (N), 98 35' 06,8 BT (E), dan ketinggian $16 \mathrm{~m}$ di atas permukaan laut. Keempat, terdapat di belakang Kilang Padi, tepi Jalan Raya Hamparan Perak-Tandam Hilir, pada kordinat $03^{\circ} 42^{\prime} 39,2^{\prime \prime} \mathrm{LU}(\mathrm{N}), 98^{\circ}$ 35' 30,7 BT (E), dan ketinggian $19 \mathrm{~m}$ di atas permukaan laut.

Kedudukan situs makam sangat memprihatinkan; makam ke-1 bahkan salah satu batu nisannya ada berhias sauh kapal sudah hilang. Makam ke-2, sebagiannya telah dibongkar orang, karena dipercayai di bawah makam terdapat harta karun. Makam ke-3, bernasib

\footnotetext{
${ }^{12}$ Tengku Luckman Sinar, "Hubungan Kerajaan Aceh Darussalam Dengan Kerajaan Haru," dalam A.Hasymy, Sejarah, h. 457.

${ }^{13}$ Tengku Luckman Sinar, Sejarah Medan Tempoe Doeloe (Medan: 2009), h. 16-17.

${ }^{14}$ Kompas Online, 24 April 2008, h. 11.
} 
sama, batu nisan sudah banyak yang tercabut dan terbiar di semak belukar. Makam ke-4, lebih buruk pula karena sudah tertimbun sampah kilang padi. Penduduk setempat tidak mengenali siapa yang dikuburkan di makam-makam tersebut, termasuk sejarah makam.

Walau demikian menurut keterangan penduduk, di kawasan ini pada tahun 1990, masih nampak tiang kapal tertanam di tengah rawa-rawa, tapi sekarang sudah tidak kelihatan. Nama desa Mojopahit dapat ditafsirkan bahwa kawasan itu sezaman dengan zaman Kerajaan Majapahit pada abad 13-15 M. Mungkin saja, tiang kapal itu adalah bekas kapal Majapahit yang pernah menyerang kerajaan Aru pada abad ke-14 M sebagaimana dikisahkan dalam syair Negarakertagama sloka 13:1. ${ }^{15}$

Empat lokasi makam di Kota Rantang terletak di dekat tebing Sungai; yaitu Sungai Lalang (Situs 4), Sungai Sei Semayang (situs 1), Sungai Diski (Situs 2) dan pertemuan Sungai Diski dan Sungai Sei Semayang (Situs 3). Hulu Sungai itu berada di deretan bukit barisan (Gunung Sibayak di Tanah Tinggi Karo dan Gunung Leuser di perbatasan Aceh-Tanah Karo) dan bermuara ke Belawan terus ke Selat Melaka. Di samping itu, terdapat pula Sungai Deli, Sungai Percut, Sungai Bedera, Sungai Wampu dan beberapa sungai lainnya yang semuanya bermuara ke Pantai Timur Sumatera.

Berdasarkan kedudukan situs makam, dapat disimpulkan makam-makam tersebut adalah makam kuno. Lokasi situs, menunjukkan bahwa kawasan itu dahulu adalah bandar penting tempat berlakunya aktivitas ekonomi dan politik di sepanjang Pantai Timur Sumatera, semasa pengangkutan darat belum berlaku. Temuan keramik di Kota Rantang dan gelas kaca (abad ke-9M), arca budha dan keramik dan lain-lain di Kota Cina tahun $1973^{16}$, memperkukuh pendapat tersebut.

Pada keempat situs makam, ditemukan lebih kurang 50 batu nisan bentuk dasar pipih (slab) dengan jenis AP2, AP3, AP4 dan AP8. Jenis nisan yang banyak dijumpai adalah jenis AP2 sebanyak 24 buah. Temuan di Kota Rantang sangat menarik, pertama dari segi jumlahnya cukup banyak, dan kedua dari jenis dan bentuk dasarnya yang sederhana dan kecil. Ukuran nisan yang terkecil adalah jenis AP8 $(5 \times 4 \times 16 \mathrm{~cm})$ dan yang besar pula jenis AP8 (22x9x40 cm). Jenis nisan di Peureulak, Samudera Pasai, Kampung Pande dan Pahang ada ditemukan di Kota Rantang. Walau bagaimanapun yang paling menarik justru jenis batu nisan AP3 tidak ditemukan tempat lain, baik di Aceh maupun di Malaysia. Dengan demikian Situs Kota Rantang penting dalam dua perkara; yaitu dari segi ukuran dan jenis nisan yang berbeda dengan situs makam di Sumatera dan Malaysia, mungkin di Asia Tenggara.

Sebuah batu nisan jenis AP8, satu-satunya batu nisan yang mengandung kalimat dalam bahasa Arab tulisan naskhi. Pada nisan bagian kaki terdapat kalimah syahadat "Lâ illâha illa Alâh Munammad Rusûl Allâh". Pada nisan bagian kepala, panel bagian atas terdapat

\footnotetext{
${ }^{15}$ Mohammad Yamin, Gadjah Mada (Jakarta: Dinas Penerbitan Balai Pustaka, 1960), h.15.

${ }^{16}$ A.C. Milner, et al., A Note On Aru, h. 12.
} 


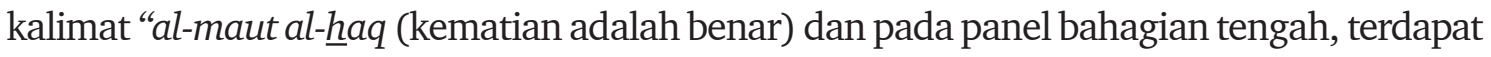
huruf ' ain dan mim ('aqmun/sanahtun = tahun) dan angka 8 titik 4 yang dapat disimpulkan merupakan tarikh 804 H/1383 M. Penaksiran 804 H tidak begitu meleset daripada kenyataan sejarah bahwa di kawasan tersebut sudah wujud Kerajaan Aru atau Haru yang pusat kerajaannya berpindah-pindah bermula daripada sekitar muara Belawan (Kota Rantang, Kota Cina ) di delta Sungai Deli sehingga ke pertemuan Sungai Babura dan Sungai Deli, dan pindah lagi ke Deli Tua/tebing Sungai Petani pada abad ke-16 M (periode terakhir).

Di Barus ada 5 kompleks makam, tetapi hanya beberapa nisan saja yang memuat angka tahun. Pecahan batu nisan di Makam Batu Badan adalah makam Tuhar Amisuri yang wafat pada $1206 \mathrm{M},{ }^{17}$ tetapi tidak dapat dikenali dari jenis nisan yang mana. Ludvik Kalus dalam Claude Gulliot, ${ }^{18}$ menegaskan makam yang paling tertua di Barus berangka tahun 1370 M, yaitu makam seorang perempuan bernama Suy yang terdapat di Kompleks Makam Ibrahim. Sementara sebuah nisan yang berasal dari Makam Mahligai yang kini ada di Museum Negeri Medan diketahui makam seorang bernama Rukn al-Din yang wafat pada bulan Shafar 800 H (15 Nopember 1397).

Makam Papan Tinggi yang terletak di atas sebuah bukit setinggi $215 \mathrm{~m}$ di atas permukaan laut terdapat makam Syaikh Mahmud yang mangkat tahun 829 H/1425-6 M. Yang menarik dari makam ini adalah digunakannya bahasa Persia dan Arab pada batu nisan Syaikh Mahmud serta jarak kedua batu nisannya sepanjang $15 \mathrm{~m}$. Berdasarkan kedudukaan batu nisan yang tidak terbenam dan warnanya yang berbeda, Ludwik Kalus meragukan keaslian makam ini. Kedua batu nisan ini ditanamkan kembali setelah lokasinya dipugar sejak tahun 1990. Ketika dilakukan studi ke Papan Tinggi tahun 1981, lokasi ini masih penuh semak belukar dan belum terdapat tangga untuk naik atas dan makam ini hanya ditandai dengan dua buah batu kali.

Dua buah batu nisan di kompleks Makam Maqdum merupakan tipe Aceh berbentuk dasar segi lapan, silindris. Terdapat silsilah nama-nama sultan yaitu al-Sultan Zayn alAbidin bin al-Sultan Muhammad bin al-Sultan Ali bin al-Sultan Yusuf bin al-Sultan Muhammad bin Musa bin al-Sultan Umar bin Abdallah. Nama-nama Sultan Zainal Abidin, Sultan Yusuf dan Sultan Ali adalah nama penguasa yang memerintah Kerajaan Aceh pada abad ke-16 M.

Belum dapat dipastikan apakah makam Maqdum merupakan makam keluarga bangsawan Aceh yang dimakamkan di sini. Mengingat setelah wafatnya Sultan Husin (Ali Riayat Syah) 8 Juni 1578 terjadi perebutan kekuasaan di Istana Aceh yang berakhir dengan serangkaian pembunuhan terhadap pengganti Sultan Husin yakni Sutan Muda, Sultan Sri Alam, Zainal Abidin, Sultan Alauddin Mansur Syah dan Sultan Buyung. Kemungkinan banyak keluarga bangsawan Aceh melarikan diri ke Barus, karena Barus merupakan wilayah kerajaan Aceh.

${ }^{17}$ Tjandrasasmita, Arkeologi Islam di Indonesia dari Masa ke Masa (Kudus: Menara Kudus, 2000), h. 17.

${ }^{18}$ Claude Gulliot, et al., Barus, h. 298-299. 
Tetapi peristiwa ini setidaknya dapat menjawab mengapa ada batu nisan tipe Aceh di kompleks makam Maqdum.

Dari kajian efigrafi dan tipologi nisan menunjukkan bahwa terdapatnya pengaruh Arab, Persia dan Cina. Tulisan di baris pertama, pada Kompleks Makam Ibrahim menggunakan kata-kata Arab yang memakai tata bahasa Persia, sedangkan di baris kedua, terdapat istilah Melayu "Tuhan" dan Cina "Syu”, nama perempuan yang meninggal, mungkin berasal dari Cina. Kesan adanya pengaruh Cina dan Persia tampak jelas pada batu nisan Makam Papan Tinggi. Karena itu dari tipologi dan jenis batu (granit), nisan di Barus (kecuali nisan di makam Maqdum) tidak menunjukkan bentuk nisan Aceh, kemungkinan di import dari Jawa, Cina atau India (Gambar 5).

\section{Islamisasi di Sumatera Utara}

Dalam Hikayat Raja-Raja Pasai dan Sejarah Melayu disebutkan bahwa Nakhoda Ismail dan Fakir Muhammad datang dari Makkah pertama mengislamkan Barus, kemudian ke Lamuri (Banda Aceh), Aru dan baru ke Pasai. Sumber sejarah ini tidak menjelaskan kapan proses islamisasi itu berlangsung. Tetapi sudah menyebut datangnya pendakwah Islam langsung dari Tanah Arab. Untuk itu, perlu dianalisis bukti arkeologi berupa batu nisan yang ada di Kota Rantang, Barus, dan beberapa sumber sejarah berupa catatan para saudagar dan pengembara Arab/Persia dan catatan Cina.

Dari periodesasinya, dipastikan jenis batu nisan di Kota Rantang sudah digunakan sejak abad ke-13 M. Nama-nama negeri dimana ditemukan jenis batu nisan ini, dapat dijadikan rujukan untuk mengenal pasti tahun batu nisan itu digunakan, disamping tarikh yang terdapat pada batu nisan tersebut. Samudera Pasai, Beruas, Melaka, Pahang adalah negeri-negeri Melayu yang sudah wujud sejak abad ke 13, 14 dan 15. Dengan demikian dapat dikatakan bahwa batu nisan di Kota Rantang tentu semasa dengan batu nisan di Samudera Pasai dan sudah digunakan pada abad ke-13. Jika demikian, maka daerah Kota Rantang, Hamparan Perak sudah menjadi kawasan penting sejak abad itu. Meskipun pada batu nisan itu tidak ada dituliskan nama tokoh yang meninggal, tetapi diduga kuat batu nisan itu adalah milik keluarga golongan bangsawan atau ulama.

Karena itu, bisa disimpulkan kawasan Hamparan Perak-Kota Cina pada masa dahulu pernah menjadi bandar perdagangan penting di tepi Selat Melaka/Pantai Timur Sumatera dan itu adalah bandar Kerajaan Aru. Kawasan ini sudah dangkal setidaknya sejak abad ke-16 M, sebagaimana disebut oleh Ali Celibi, seorang Laksamana Kerajaan Turki yang pernah mengujungi Bandar Aru. Ini merupakan salah satu sebab mengapa istana Kerajaan Aru dipindahkan ke hulu Sungai Deli.

Jika demikian, maka Kerajaan Aru/Haru sudah dipastikan sebagai Kerajaan Islam sejak pertengahan abad ke-13 M. Kesimpulan ini didasarkan kepada pada jenis batu nisan di Kota Rantang, Hikayat Raja-Raja Pasai, Sejarah Melayu, Kunjungan Marcopolo 1292 M, 
batu nisan Sultan Malikul Saleh, 1297 M. Tidak diketahui siapakah penguasa Aru yang pertama kali memeluk agama Islam. Sumber Cina menyebutkan bahwa nama Aru/Haru pertama kali muncul pada tahun 1282 M ketika mengirimkan utusan untuk menemui Kaisar Kubilai Khan.

Nama penguasa Aru baru jelas disebutkan dalam catatan Dinasti Ming. Raja Aru So-lo-tan Hut-Sin (Sultan Husin) mengirim utusan pada tahun 1407 menemui Kaisar Yung Lo membawa gading gajah. Nama Sultan Husin menjadi bukti yang kuat bahwa Kerajaan Aru telah beragama Islam. Selanjutnya secara berturut Tuan A-la-sa (Alamsyah) putera Sultan Husin mengirimkan utusan ke Cina tahun 1410, 1421 dan 1423. Sebagai balasannya, Kaisar Cina mengirim Laksamana Cheng Ho yang beragama Islam ke Aru tahun 1412 dan 1431. Mahuan kemudian menegaskan bahwa pada tahun 1451 raja Haru beserta rakyatnya telah memeluk agama Islam. ${ }^{19}$

Berdasarkan itu tidak tepat bila dikatakan Kerajaan Haru yang kekuasaanya dari Tamiang sampai Rokan (Riau) diislamkan oleh Kerajaan Aceh Darussalam. Memang Haru sejak 1524 sudah ditaklukkan Kerajaan Aceh Darussalam di bawah Sultan Ali Mughayat Syah. Tetapi perlu diingat bahwa sekitar tiga abad sebelum Kerajaan Aceh wujud, Kerajaan Haru sudah memeluk agama Islam dan bisa dipastikan agama Islam sudah berkembang di Sumatera Utara. Dengan begitu serbuan Sultan Aceh, al-Khahar ke Aru yang kemudian disebut Ghori/Deli lebih tepat sebagai usaha Sultan Aceh mengatasi pemberontakan di Aru/Ghori dan mengusir Portugis dari Sumatera Utara.

Dapat dipastikan Islam sudah masuk ke Sumatera Utara, jauh sebelum Kerajaan Aceh Darussalam berdiri. Bahkan jauh sebelum Kerajaan Haru memeluk Islam pada pertengahan abad ke-13 M. Para ahli sejarah sepakat, bahwa agama Islam masuk ke Indonesia melalui jaringan perdagangan. Diketahui bahwa sejak awal Masehi (abad II dan III M) kawasan Asia Tenggara sudah ramai dikunjungi para saudagar dari Yunani, Arab, Parsi, Cina, dan India. Kapal-kapal perniagaan dari berbagai bangsa itu tiba di gugusan pulau Melayu (Sumatera, Semenanjung Malaysia, Kalimantan, Jawa dan Sulawesi) karena daerah ini kaya dengan hasil bumi yaitu rempah-rempah.

Karena kedudukannya yang begitu penting secara ekonomi dan geografi, maka kedudukan pulau-pulau di Asia Tenggara menjadi tempat pertemuan dari berbagai agama dan kebudayaan. Tidak mengherankan apabila pada abad VI M sudah ada komunitas orang Parsi sebanyak 500 keluarga yang masih menganut agama Zoroaster bertapak di Ligor, Utara Semenanjung Tanah Melayu. ${ }^{20}$

Saudagar-saudagar Arab ini datang ke gugusan tanah Melayu lama sebelum Islam. Mereka datang dari dua jalan; Pertama jalan laut: dimulai dari Aden (semenanjung Tanah

${ }^{19}$ J.V.G. Mill (ed.), Ma Huan Ying-Yai Sheng Lan: The Overall Survey of the Ocean's Shores [1433] (Hakluyt Society: Cambridge University Press, 1967), h. 114-115.

${ }^{20}$ A.Hasymy, Sejarah, h. 175. 
Arab menuju ke Gujarat, Cambay, Sailan, dan dari sini bertolak ke gugusan pulau Melayu (Asia Tenggara). Kedua, jalan darat: dimulai dari Damsyik (Syria), ke Khurasan (Parsi) dan dari Khurasan ke Balakh (Afghanistan), dan dari Balakh ke Bamir kemudian ke Kasykar, Shina, ke Sangtu, kemudian ke Hansyau dan dari sinilah mereka bergerak ke gugusan pulau Melayu (Asia Tenggara). Kebanyakan para saudagar Arab itu adalah penduduk di Selatan Semenanjung Tanah Arab. Nabi Muhammad SAW. memerintahkan Mu'az Ibn Jabal untuk mengislamkan daerah ini pada 630 M. Maka dapat diperkirakan bahwa para saudagar Arab yang selalu berniaga ke Asia Tenggara sudah memeluk agama Islam pada abad ke-7 M atau sebelumnya.

Perjalanan kapal-kapal dari Teluk Aden ke gugusan pulau Melayu bergantung kepada angin, begitu pula sebaliknya. Pelayaran dari Aden bergantung kepada angin Barat Laut yang berhembus di bulan September yang membawa kapal-kapal ke pesisir pantai India Selatan dan dari sini masuk ke gugusan pulau-pulau Melayu dan terus ke Cina. Sementara perjalanan pulang dari Gugusan Pulau Melayu bergantung kepada angin Timur Laut yang bertiup di akhir bulan Desember yang membawa kapal-kapal mereka dari gugusan pulau Melayu menuju pesisir pantai India Selatan dan dari sini menuju ke Semenanjung Tanah Arab. Karena itu para saudagar Arab Muslim ini harus tinggal beberapa lama di Pesisir Sumatera. ${ }^{21}$ Pada ketika inilah diperkirakan mereka melakukan dakwah Islam di kalangan penduduk lokal. Dalam konteks ini, maka Sumatera Utara menjadi tempat yang strategis secara ekonomi dan geografi. Karena itu tidak mengherankan apabila di sepanjang pesisir Timur Sumatera bermunculan bandar-bandar perdagangan.

Berdasarkan itu maka agama Islam bisa dipastikan sudah sampai ke Sumatera Utara pada abad ke-7 M. Hal ini diperkuat dengan laporan kronik Dinasti Tang menyatakan bahwa terdapat sebuah komunitas orang Ta Shih (Tajik= Orang Parsi Islam) mengurungkan niatnya menyerang Kerajaan Holing yang diperintah Ratu Sima pada $674 \mathrm{M} .{ }^{22}$ Komunitas orang Ta Shih itu letaknya 5 hari pelayaran dari Chopo di seberang Selat Melaka. Para ahli berbeda pendapat mengenai lokasi Ta Shih. ${ }^{23}$ Berdasarkan lama jarak pelayaran menuju komunitas

${ }^{21}$ Pengalaman pendeta Budha, It Tsing yang berangkat dari India ke China dan sebaliknya, ia tinggal di Sriwijaya abad ke 7 M dan Marcopolo singgah di Pasai pada tahun 1292 M ketika dalam perjalanan dari China hendak ke Istana Iran di Khurasan adalah bukti kuat bahwa pesisir Sumatera menempati posisi penting secara ekonomi dan geografi pada ketika itu. ITsing, A Record of The Budhist Religion as practised in India And The Malay Archipelago (A.D. 671-695), terj. J.Takakusu (Oxford: At The Clarendon Press, 1896) dan Henry Yule, The Book of Ser Marcopolo, the Venetian, Concerning the Kingdoms and Marvels of the East (London: John Murray, Albemarle Street, 1871).

${ }^{22}$ W.P.Groeneveldt, Historical notes on Indonesia and Malaya compiled from Chinese sources (Djakarta: C.V. Bhratara 1960), h. 14.

${ }^{23}$ Mohd. Said. Aceh Sepanjang Abad (Medan: Waspada, 1981), h.26-27 dan Mohd. Yamin, Gadjah Mada, h. 9a, menyatakan Ta Shih berada di Samudera Pasai (Aceh Utara); W.P. Groeneveldt, Historical, h.14 menyatakan di Sumatera Barat tanpa merujuk dengan lokasinya. Hamka dalam A.Hasymy, Sejarah, h.9, menyatakan Ta Shih adalah kerajaan Mu'awiyah bin Abi Sofyan yang 
Ta Shih, maka diperkirakan komunitas orang Parsi-Islam itu berada di Utara Sumatera. Utara Sumatera yang dimaksudkan di sini meliputi Daerah Sumatera Utara sekarang sampai ke Aceh Timur dan Aceh Utara.

Berdasarkan bukti-bukti arkeologi batu nisan Sultan Alaeddin Syed Maulana Abdul Aziz Shah di desa Bandrong, Kitab Idharul Haq dan Sejarah Melayu, maka komunitas Orang Ta shih itu kemungkinan besar adalah di daerah Peureulak, Aceh Timur. Groeneveldt menyatakan pada tahun 674 M seorang Arab telah diangkat mengepalai orang-orang Muslim di Ta Shih (Tazi). Komunitas orang-orang Ta Shih inilah yang mengislamkan para Meurah di negeri Peureulak melalui perkawinan dan membangun Kerajaan Peureulak, sebagaimana diceritakan dalam Kitab Idharul Haq. ${ }^{24}$

Kasus kehadiran komunitas Ta Shih dan berdirinya Kerajaan Peurelak Islam sebenarnya membuktikan bahwa kawasan Utara Sumatera (Peurelak, Pasai, Aru ) pada abad ke-7 dan $8 \mathrm{M}$ sudah ramai didatangi para saudagar dari negeri Arab, Parsi dan India. Kehadiran saudagarsaudagar Arab di Sumatera Utara diperkuat dengan temuan berbagai barang perdagangan di situs Kota Cina, terutama Islamic glasses dari Timur Tengah, yang dibawa oleh para saudagar Arab ke daerah ini sekitar abad-abad ke-9-11 M.

Namun bagaimana perkembangan Islam di Sumatera Utara hingga penguasa Haru memeluk agama Islam pada pertengahan abad ke-13 M. Tidak ada sumber sejarah yang menjelaskan peristiwa ini. Bukti-bukti arkeologis berupa batu nisan tipe Aceh di Kota Rantang hanya satu yang mempunyai tarikh abad ke-14 M (1383 M). Sementara nisan Aceh di Klumpang, Hamparan Perak yang dikenali sebagai makam Imam Sadiq ibn Abdullah bertarikh 998 H/1590 M (abad XVI). Begitu juga dengan nisan yang ada di Barus bertarikh yang tertua pada abad ke-13 dan abad ke-14 M. Dari data efigrafi yang dijumpai tidak banyak yang dapat digunakan untuk menerangkan proses islamisasi di Sumatera Utara masa itu.

Sebuah sumber tradisi, Hikayat Hamparan Perak merupakan satu-satunya sumber yang menjelaskan bagaimana proses Islamisasi di Sumatera Utara. Tetapi sumber yang berkisah tentang genealogi Guru Patimpus ini berkisah tentang bagaimana proses Islamisasi terhadap orang-orang Batak di pedalaman oleh orang yang dipanggil dengan nama Datuk Kota Bangun atau Orang Jawi dari Seberang, pada abad ke-17 M, saat Haru sudah hancur dan dikuasai oleh Kerajaan Aceh. Siapakah Datuk Kota Bangun? Apakah ia Imam Sadik Ibn Abdullah yang makamnya ada di Klumpang? Masih memerlukan kajian lebih mendalam.

Proses Islamisasi versi Hikayat Hamparan Perak terjadi karena adanya kekhawatiran Orang-Orang Batak/Karo di pegunungan atas semakin berkembangnya Islam di daerah pesisir pantai, yakni banyaknya orang-orang Karo yang telah menjadi Islam (Masuk Melayu). Guru Patimpus berkata “...kita punya tanah sampai ke laut, aku pikir jikalau tiada aku masuk

terletak di Jazirah Arab; Wan Husein Azmi dalam A. Hasymy. Sejarah, h.93, menyatakan di Sumatera Utara (Aceh Timur, Aceh Utara dan Sumatera Utara).

${ }^{24}$ A.Hasymy, Sejarah, h. 195. 
Islam, tentulah tanah kita yang dekat laut diambil oleh Jawi dari seberang...”. Karena itulah, maka Guru Patimpus beserta 7 orang besarnya masuk Islam dan berguru dengan Datuk Kota Bangun selama 3 tahun. Ketika itu Kampung Pulau Berayan yang dirajai oleh orang Karo bermarga Tarigan telah lama masuk Islam. Guru Patimpus kemudian mengawini puteri Raja Pulau Berayan dan mempunyai dua anak bernama Hafiz Tua dan Hafiz Muda. Kedua puteranya ini pun berguru agama Islam dengan Datuk Kota Bangun. ${ }^{25}$

Imam Sadiq ibn Abdullah pastilah seorang ulama yang mengembangkan agama Islam di Sumatera Utara pada abad ke -16 M. Diperkirakan ia adalah ulama yang datang dari Aceh bersamaan dengan usaha Kerajaan Aceh Darussalam untuk mengislamkan daerah pedalaman Batak dan penaklukkan Kerajaan Haru/Ghori oleh Sultan Aceh Saidil al-Mukamil. Kedudukan makam yang berada di Klumpang, berdekatan dengan tebing Sungai Lalang merupakan bukti bahwa Imam Sadiq banyak melakukan dakwah Islam kepada orangorang Karo yang datang dari Gunung melalui Sungai Lalang untuk berniaga atau menemui kerabat-kerabatnya yang sudah lebih dulu bermukim di daerah Sunggal atau ke pesisir pantai (Hamparan Perak, Buluh Cina dan Labuhan).

Dengan begini, akan dianalisis batu nisan Kota Rantang dan Barus untuk membentuk teori mengenai Islamisasi di Sumatera Utara sebelum abad ke-13 M. Berdasarkan tipologinya, batu nisan yang ada di Kota Rantang serupa dengan batu nisan yang ada di Peurelak dan Pasai. Cirinya yang sederhana, tanpa dekorasi yang rumit menunjukkan bahwa proses Islamisasi di daerah ini masih sangat awal, artinya masih belum banyak pakar pengukir batu nisan sebagaimana pada masa Kerajaan Samudera Pasai dan Aceh Darussalam.

Kesimpulan ini memang masih dapat diperdebatkan, tetapi jika kitab Idharul Haq dapat dipercaya maka, diperkirakan Islamisasi di daerah ini sudah berlaku sezaman dengan yang terjadi di Kerajaan Peureulak yaitu sejak abad ke 9-10 M. Peureulak menjadi kerajaan pertama yang beragama Islam dengan rajanya bergelar Sultan Syed Maulana Abdul Aziz Shah (840-864 M). Kerajaan ini kemudian menjadi pusat dakwah Islam di Asia Tenggara yang mengislamkan beberapa bandar-bandar penting di Utara Sumatera termasuk Pasai dan Aru.

Temuan sekitar 50 batu nisan di Kota Rantang, Hamparan Perak dengan jenis dan tipologi yang sama dengan di Peurelak dan Pasai membuktikan bahwa kawasan Kota Rantang merupakan kawasan penting dari Kerajaan Haru. Kompleks pemakaman keluarga istana biasanya tidak jauh dari tempat bersemayam raja (istana). Konsep Kota Kerajaan Tradisional selalu menempatkan Istana Raja, Masjid, Pasar, Alun-alun serta kompleks pemakaman keluarga raja/bangsawan yang saling berdekatan. Dari sini dapat disimpulkan Kota Rantang merupakan tempat pemakaman keluarga Kerajaan Haru yang berpusat di Kota Cina (Labuhan Deli).

Bandar Kerajaan Haru di Kota Cina ini bertahan hingga akhir abad ke-13 M. Luckman

${ }^{25}$ Sinar, Sejarah Medan, h. 8-21. 
Sinar ${ }^{26}$ memperkirakan, Kota Cina hancur karena serangan Majapahit (1350 M) atau letusan Gunung Sibayak yang menimbulkan gempa sehingga menghancurkan Candi Buddha di Kota Cina. Berdasarkan temuan archa Buddha dan bekas-bekas Candi Budha yang tertimbun tanah sedalam lebih kurang 1 meter, maka Kerajaan Haru kemungkinan sebelumnya adalah menganut agama Buddha.

Sekarang, akan dilihat kasus pantai Barat Sumatera. Barus yang terletak di pantai Barat Sumatera Utara, merupakan kawasan penting sejak awal-awal abad Masehi. Orang-orang Cina sudah mengenal Barus sejak abad ke-6 M yang selalu dikaitkan dengan penghasil kamper, dengan nama Poluosua, Polu, Polushi dan Polu. ${ }^{27}$ Demikian pula para pelaut Arab $(851 \mathrm{M})$ mengenalnya dengan nama Fanshur yang menghasilkan banyak kamper. ${ }^{28}$

Namun penggalian di situs Lobu Tua, menunjukkan Barus masuk dalam jaringan perdagangan dengan Timur Tengah mulai abad ke-9 M. Temuan kaca berupa pecahan mangkok, piring, gelas, tabung kimia, cerek dan botol dan pecahan keramik dalam berbagai bentuk menunjukkan Barus sudah menjalin hubungan dengan bandar-bandar perdagangan di wilayah Timur Tengah, seperti Siraf, Mesopotamia, Naisabur atau Gurgan (Utara Iran) dan Pantai Makram. Ini mengindikasikan bahwa Teluk Persia memiliki hubungan perdagangan khusus dengan Barus. Bahkan sejak abad ke-4 M, orang-orang Parsi Kuno sudah mengenal kamper sebagai bahan obat-obatan. Siraf merupakan bandar terkemuka pengimpor kamper dan kamper merupakan bahan obat-obatan yang paling laku di pasaran Timur Tengah ketika itu. ${ }^{29}$

Namun begitu, belum dapat dipastikan bahwa pada abad-abad itu orang-orang Parsi, Arab, Cina dan India datang langsung ke Barus untuk mengambil kamper. Kamper mungkin diperoleh dari bandar-bandar di Sumatera Utara atau Timur (Lamuri, Pasai, Perlak, dan Haru) sebagaimana dijelaskan oleh Pires pada abad ke-16 M. ${ }^{30}$ Orang Cina baru pada abad ke $15 \mathrm{M}$ sampai di Barus itu pun karena kapal-kapal mereka terserang badai hingga terpaksa mendarat di Barus. Mereka justru mendapatkan kamper dari Brunai.

Kamper telah menghubungkan Barus dengan pusat dunia Islam di Timur Tengah setidaknya sejak abad ke-9 M. Berdasarkan jumlah keanekaragaman benda-benda dari Timur Tengah, termasuk manik-manik dan jimat dari batu bertuliskan huruf kufi, ${ }^{31}$ menduga bahwa sekelompok masyarakat yang berasal dari Timur Tengah pernah menetap di Barus, sejak abad ke-9.

\footnotetext{
${ }^{26}$ Tengku Luckman Sinar, "Kerajaan Haru Yang Islam Berpusat di Deli Tua," dalam Sangkhakala, Vol. XI No. 22 (Oktober, 2008), h. 116.

${ }^{27}$ O.Wolters, Early Indonesian Commerce (Ithaca: Cornel University Press 1967), h. 184186; Claude Guillot (ed.), Barus, h. 34.

${ }^{28}$ Claude Guillot (ed.), Lobu Tua Sejarah Awal Barus (Jakarta: Yayasan Obor Indonesia 2002), h. 215-220.

${ }^{29}$ Claude Guillot, et al., Barus, h. 57.

${ }^{30}$ Armando Cortesao (ed.), The Suma Oriental of Tome Pires, Vol. II (London: Haklyut Society, 1944), h. 146.

${ }^{31}$ Claude Guillot, et.al., Barus, h. 42-45.
} 
Tetapi jumlahnya tidak lebih banyak dari orang India yang lebih awal datang ke Barus. Kronik Hulu pula telah memuat tradisi dimana orang Arab pernah datang dan menetap di Barus karena tertarik dengan kegiatan perdagangan yang dikembangkan oleh orang Chettiar (pendatang India).

Guillot pun merujuk beberapa bukti tentang adanya pedagang Timur Tengah, terutama dari Khorasan (Iran) di Barus, seperti sudah dikenalnya kamper (kapur barus) pada masa dinasti Sassanid abad ke-4 M di Iran, pertemuan antara, Ibnu Battuta dengan seorang ulama dari Tus pada abad ke-15 M dan laporan orang Portugis tentang sejumlah pedagang "Coracoes" (Persia) berada di India dan India Timur. Namun karena jumlah mereka tidak banyak, sehingga tidak dapat membentuk sebuah komunitas yang berpengaruh, paling tidak hingga abad ke-13 M (1206) atau abad ke-14 M merujuk kepada nisan Tuhar Amisuri dan makam seorang perempuan bernama Syu dan lainnya di Kompleks Makam Ibrahim.

Sumber sejarah pribumi berupa Kronik Hulu (Asal Keturunan Raja Barus) dan Kronik Hilir (Sejarah Tuanku Batu Badan) bukan menjelaskan Islamisasi di Barus, tetapi proses pengislaman di Tanah Batak. Menurut Kronik Hilir, Sultan Ibrahim karena berselisih dengan ayahnya Sultan Muhammad Syah pergi ke Silindung, Pasaribu, Bakara kemudian mengawini putri raja Bakara dan melahirkan anak bernama Singa Maharaja. Kronik ini juga menjelaskan perselisihannya dengan Sultan Aceh yang berakhir dengan pemenggalan kepalanya oleh Sultan Aceh. ${ }^{32}$ Kedua kronik ini diciptakan pada abad ke-19 M dan diperkirakan peristiwa yang dipaparkan berlaku pada abad ke-16 M. Islam pada masa ini sudah berkembang pesat dan Barus sendiri sudah diperintah oleh raja-raja Islam yang bergelar sultan dan Barus bagian dari Kerajaan Aceh.

Ketiadaan data arkeologi yang mengindikasikan terdapatnya kumpulan saudagar Arab di Barus pada abad ke (7-12 M), bukan berarti Islam belum sampai di Barus. Secara logik, mana mungkin orang-orang Parsi yang sudah mengenal kamper sejak abad ke-4 M dan orang-orang Arab sudah mengenal kapur barus paling tidak sejak abad ke-9 M, tidak sampai ke bandar Barus sebagai salah satu daerah penghasil kamper utama di Tanah Melayu. Para saudagar Arab-Persia pasti lebih senang membeli langsung ke tempat asalnya, dengan pertimbangan harga lebih murah daripada membeli melalui perantara bandar lain di Sumatera Utara dan Timur. Mungkin saja sampai hari ini belum diketemukan data mengenai kehadiran mereka di Barus pada abad itu. Kajian arkeologi dan sejarah ke depan mungkin dapat menemukan bukti-bukti baru yang mendukung teori di atas.

Orang-orang Arab sangat membutuhkan kapur barus karena benda itu sudah disebutkan dalam Q.S./76: 5, Sesungguhnya orang-orangyang berbuat baik meminum dari gelas (minuman tersebut) bercampur dengan kapur [nama tumbuh-tumbuhanyang harum baunya]. Pentingnya

\footnotetext{
${ }^{32}$ Jane Drakard, Sejarah Raja-Raja Barus, Dua Naskah dari Barus (Jakarta-Bandung: Penerbit Angkasa dan EFEO, 2003), h. 27-38.
} 
kapur barus dalam masyarakat Muslim diperkuat oleh hadis Nabi Muhammad SAW. yang diriwayatkan Jama'ah dari Ummu 'Athiyyah sebagai berikut;

'...Rasulullah SAW. masuk menemui kami ketika putrinya meninggal, maka sabdanya: Mandikanlah ia tiga atau limau atau beberapa kalian yang dianggap perlu, lebih banyak lagi, dengan air dan bidara dan terakhir campurlah dengan kapur (kapur barus) atau sedikit dari kapur (kapur barus). Jika sudah selesai, beritahukanlah saya. Setelah selesai, kami memberitahu Nabi, maka diserahkannya kepada kami kain sarungnya, serta sabdanya: lilitkanlah pada badannya... ${ }^{33}$

Keperluan masyarakat Arab dan Timur Tengah akan kapur barus dan hasil bumi Sumatera lainnya dimanfaatkan oleh para pedagang Muslim-Arab untuk sekalian menyebarkan agama Islam kepada para pedagang Melayu di Nusantara. Tidak mengherankan apabila pada abad ke 8 dan 9 M komunitas pedagang Muslim sudah muncul di tepian Selat Melaka, seperti di Kedah, Barus, Lamuri, Pasai, Perlak, Aru dan ibukota Sriwijaya.

\section{Penutup}

Proses islamisasi di Sumatera Utara tidak lebih lama dari yang berlaku di Pasai. Masyarakat pesisir Timur Sumatera Utara telah menerima pengaruh Islam melalui perkenalannya dengan saudagar dari Arab/Persia dan India. Proses Islamisasi itu akhirnya membentuk sebuah komunitas politik bercorak Islam pada abad ke-13 M yakni munculnya Kerajaan Haru. Kerajaan Haru yang Islam sudah muncul sejak istananya berada di Kota Cina/Kota Rantang, Hamparan Perak, di delta Sungai Deli.

Namun Haru tidak muncul sebagai agen penyebar agama Islam di wilayah Sumatera Utara, meskipun Haru menjadi Kerajaan kuat di Sumatera Utara pada abad ke-15. Posisi ini dipegang oleh Kerajaan Pasai dan Malaka sampai akhir abad ke-15. Pada masa ini agama Islam sudah menyebar sampai ke wilayah pedalaman di Hulu Sungai Deli. Pemukimanpemukiman Muslim diperkirakan muncul pula di sepanjang aliran Sungai Lalang, Sei Semayang dan Diski dari mulai Hamparan Perak, Buluh Cina, Kelambir Lima dan Sunggal, sebagaimana terdapatnya beberapa kuburan kuno dengan nisan tipe Aceh di daerah ini.

Memasuki abad ke-16-17, agama Islam sudah memasuki wilayah dataran Tinggi Karo, Simalungun, Dairi dan sebahagian Tanah Batak. Islamisasi berjalan bersamaan dengan hadirnya Aceh sebagai kekuatan Islam yang dominan di Asia Tenggara menggantikan posisi Pasai dan Melaka sejak awal abad ke-16 M. Serangan Aceh atas Haru menimbulkan perubahan politik yang mengarah terbentuknya kekuatan politik baru di atas reruntuhan Aru. Deli, Asahan, Langkat dan Serdang kemudian muncul pada abad ke-17 sebagai Kerajaan Melayu yang bercorak Islam dan menampilkan diri sebagai agen penyebar agama Islam

${ }^{33}$ Dikutip dari Zainulfakar, "Teori Kedatangan Islam ke Alam Melayu: Suatu Analisis Hubungan Teori dan Realiti Sejarah [http://zainulfaqar.wordpress.com/2007/10/21/], h.7-8. 
di Sumatera Utara. Kerajaan-kerajaan ini mampu membangun masjid-masjid megah sebagai simbol semakin berkembangnya agama Islam di Sumatera Utara, diantaranya Masjid Al-Osmani di Labuhan.

Bukti arkeologi batu nisan di Barus memang tidak ada yang lebih tua dari abad ke$13 \mathrm{M}$, tetapi perlu diingat bahwa batu nisan Tuhar Amisuri wafat sekitar 90 tahun lebih dulu daripada Sultan Malikul Saleh. Ini bermakna bahwa Islam pasti sudah hadir lebih lama di Barus atau setidak-tidaknya sezaman dengan Pasai dan Peurelak. Batu nisan bukan tipe Aceh di Barus yang mirip dengan nisan di Jawa dan mirip dengan model kuburan orang Cina, perlu dikaji lebih dalam untuk mengungkapkan misteri di balik kehadirannya di Barus.

Studi arkeologi di Lobu Tua, menghasilkan temuan berupa mata uang berlambang cendana yang serupa dengan mata uang di Jawa masa abad ke-10 M. Studi ini mengindikasikan telah terjadi hubungan perdagangan antara Barus dan Jawa melalui Pantai Barat Sumatera pada abad-abad ke-10 dan 11 M. ${ }^{34}$ Kemungkinan dari sinilah masuk model nisan Jawa ke Barus, dan di Leran Gresik, sudah diketemukan sebuah nisan kubur Fatimah binti Maimun yang mangkat pada tahun $1028 \mathrm{M}$. Dari segi tipologi nisan di Barus lebih mirip dengan nisan di Brunai (1048 M) dan di Jawa. Di komplek perkuburan Islam Ranggas, Bandar Sri Begawan dijumpai sebuah nisan bertuliskan bahasa Cina dengan tarikh 1264 M yang tercatat nama Tuan Pu. Apakah Islamisasi di Barus telah terjadi melalui Cina-Brunai-dan Jawa. Ini sebuah isu penting untuk mengungkap misteri sejarah Barus secara holistik.

\section{Pustaka Acuan}

Ambary, Hasan Muarif. Menemukan Peradaban: Jejak Arkeologis dan Historis Islam Indonesia. Jakarta: Logos Wacana Ilmu, 2001.

Arifin, M. Perkembangan Islam di Peureulak Khususnya dan Aceh Timur Umumnya. Langsa: Majelis Ulama Daerah Tk.II Kab. Aceh Timur, 1980.

Cortesao, Armando (ed.). The Suma Oriental of Tome Pires, vol.II. London: Haklyut Society, 1944.

Drakard, Jane. Sejarah Raja-Raja Barus, Dua Naskah dari Barus. Jakarta-Bandung: Penerbit Angkasa dan EFEO, 1998.

Groeneveldt, W.P. Historical Notes on Indonesia and Malaya compiled from Chinese sources. Djakarta: C.V. Bhratara, 1960.

Guillot, Claude (ed). Lobu Tua Sejarah Awal Barus. Jakarta: Yayasan Obor Indonesia, 2002.

Guillot, Claude, et.al. Barus Seribu Tahun Yang Lalu. Jakarta-Paris: Kepustakaan Populer Gramedia, 2008.

Guillot, Claude dan Ludvik Kallus, Inskripsi Islam Tertua Di Indonesia. (Jakarta: Gramedia, 2008).

Hasymy, A. Sejarah Masuk dan Berkembangnya Islam di Indonesia. Medan: PT Almaarif, 1981.

${ }^{34}$ Calude Guillot (ed.), Barus, h. 52-53. 
I-Tsing. A Record of The Budhist Religion as practised in India And The Malay Archipelago (A.D. 671-695), terj. J.Takakusu. Oxford: At The Clarendon Press, 1896.

Iskandar, Teuku (ed.). Bustanu's Salatin Oleh Nuruddin ar-Raniri (Kuala Lumpur: Dewan Bahasa dan Pustaka, 1966).

Luckman Sinar, Tengku. Sejarah Medan Tempoe Doeloe, cet.17. Medan: tp., 2009.

Luckman Sinar, Tengku. "Sejarah Kesultanan Melayu di Sumatera Timur" dalam Melayu Online.Com. 22 November 2007.

Luckman Sinar, Tengku. "Kerajaan Haru Yang Islam Berpusat Di Deli Tua" dalam Sangkhakala, vol. XI, no. 22. Oktober, 2008.

Luckman Sinar, Tengku. "Hubungan Kerajaan Aceh Darussalam Dengan Kerajaan Haru," dalam A.Hasymy. Sejarah Masuk Dan Berkembangnya Islam Di Indonesia. Medan: PT Almaarif, 1981.

Millner, A.C., et.al. "A Note On Aru and Kota Cina," dalam Melayu Online.Com, 13-15 Maret 2008.

Mill, J.V.G. (ed.). Ma Huan Ying-Yai Sheng Lan: The Overall Survey of the Ocean's Shores [1433]. Hakluyt Society: Cambridge University Press, 1967.

Othman, Modh Yatim. Batu Aceh Early Islamic Gravestones in Peninsular Malaysia. Kuala Lumpur: Museum Association of Malaysia c/o Muzium Negara, 1988.

Othman, Mohd. Yatim dan Halim Nasir. Epigrafi Islam Terawal di Nusantara. Kuala Lumpur: Dewan Bahasa dan Pustaka Kementerian Pendidikan Malaysia, 1990.

Said, Mohd. Aceh Sepanjang Abad, cet.2. Medan: Waspada, 1981.

Shellabear, W.G. Sejarah Melayu. Singapura: Malaya Publishing House, 1986.

Sircom, H.S. "Keramat in Lower Pahang," dalam Journal of the Federated Malaya State Museum. Vol. IX, 1920.

Suprayitno. "Kota Rantang dan Hubungannya dengan Kerajaan Aru," dalam Waspada. 18 Mei 2008.

Tjandrasasmita, Uka. Arkeologi Islam di Indonesia dari Masa ke Masa. Kudus: Menara Kudus, 2000.

Wolters, O. Early Indonesian Commerce. Ithaca: Cornel University Press, 1967.

Yamin, Muhammad. Gadjah Mada. Jakarta: Dinas Penerbitan Balai Pustaka, 1960.

Yule, H. C. The Book of Ser Marcopolo, the Venetian, Concerning the Kingdoms and Marvels of the East. London: John Murray, Albemarle Street, 1871.

Zainulfakar. "Teori Kedatangan Islam ke Alam Melayu: Suatu Analisis Hubungan Teori dan Realiti Sejarah,” dalam http:// zainulfaqar.wordpress.com/2007/10/21. 